\title{
Neonatal seizures: an emergency condition commonly seen in neonatal intensive care unit
}

\author{
Deepak Sharma, Aakash Pandita, Srinivas Murki, Oleti Tejo Pratap
}

Department of Neonatology, Fernandez Hospital, Hyderabad, Andhra Pradesh, India

Correspondence to Dr Deepak Sharma, dr.deepak.rohtak@gmail.com

Accepted 15 October 2014

\section{DESCRIPTION}

\section{Cases}

A term male baby with an Apgar score of $8 / 8 / 9$ was admitted to our hospital at $24 \mathrm{~h}$ of life with abnormal body movements. The infant had multifocal myoclonic seizures that started in the lower limbs with secondary generalisation to the whole body; this condition was associated with desaturation (video 1). The numerous episodes of seizures required multiple anticonvulsants. MRI of the brain showed a normal study and the infant was discharged on phenobarbitone.

In another case, a 2-day-old term male infant was referred to our hospital in view of respiratory distress and with possible cyanotic heart disease. The baby was diagnosed as a case of Vein of Galen malformation as a head ultrasound showed an echolucent structure in the posterior region of midline, superior to tentorium cerebellum and thalami. This infant had neonatal seizure episodes each of approximately 2 min duration in the form

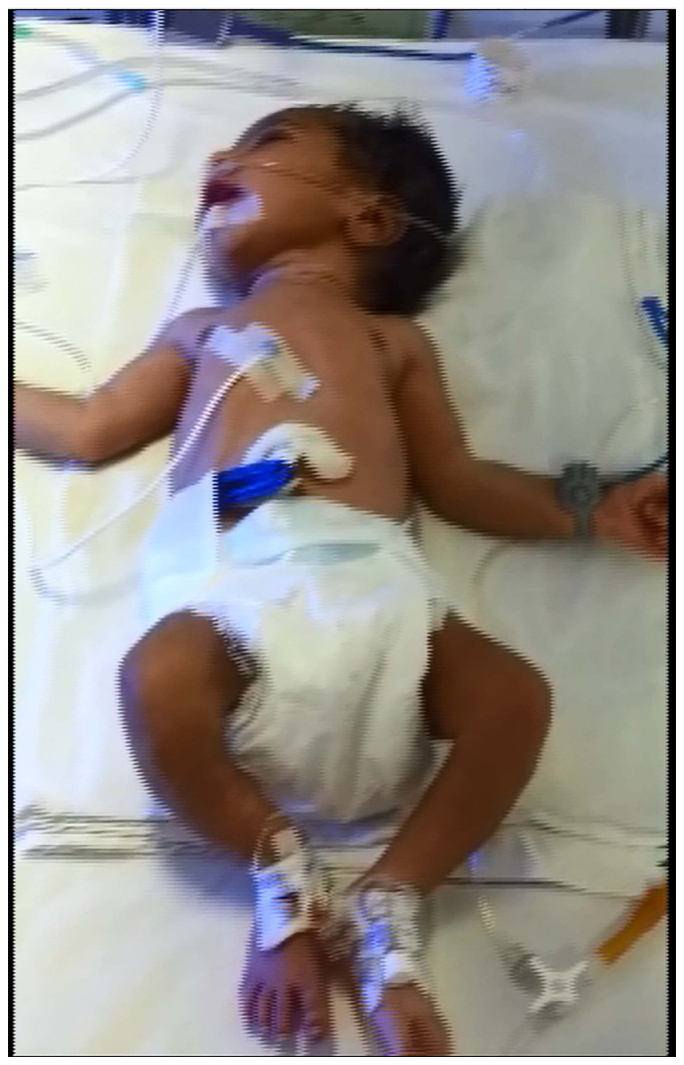

To cite: Sharma $D$, Pandita A, Murki S, et al. BMJ Case Rep Published online: [please include Day Month Year] doi:10.1136/ bcr-2014-206577

CrossMark
Video 1 video showing multifocal myoclonic seizures in the infant. The seizures started in lower limbs and then starting in upper limbs. On that point are also twitching movements of the face. Also see associated distortion with an infant. of cycling movements of the lower limbs associated with tachycardia (video 2). The infant was started on anticonvulsants and there was no recurrence of seizures.

\section{DISCUSSION}

Neonatal seizures represent the most specific and distinctive sign of neurological abnormalities in newborns and are the manifestation of many aetiologies, ${ }^{1}$ the most common being hypoxic ischaemic encephalopathy, intracranial bleeding, intracranial infections, developmental defects, hypoglycaemia, hypocalcaemia, inborn error of metabolism and epileptic syndromes. ${ }^{2}$ Therefore it is vital to identify these seizures, find their causes and establish appropriate treatment.Listed below are four essential types of seizures ${ }^{3}$ :

1. Subtle seizure: most common type

2. Clonic seizure
A. Focal
B. Multifocal

3. Tonic seizure
A. Focal
B. Generalised

4. Myoclonic seizure
A. Focal, multifocal
B. Generalised

Subtle seizures can manifest in several forms such as chewing, paddling, cycling, boxing and ocular movements; the most common of these is the ocular phenomenon. Myoclonic seizures have the worst prognosis of all neonatal seizures. Generalised myoclonic seizures are well localised, migrating jerky movements and usually involve the arms. Myoclonic seizures must be differentiated from clonic seizures. ${ }^{45}$

Neonatal seizures must be differentiated from jitteriness. ${ }^{6}$ The cause must be found and the seizure treated accordingly. Diagnosis requires a high level of suspicion, and experience is imperative for recognising the type of seizure. Detailed history

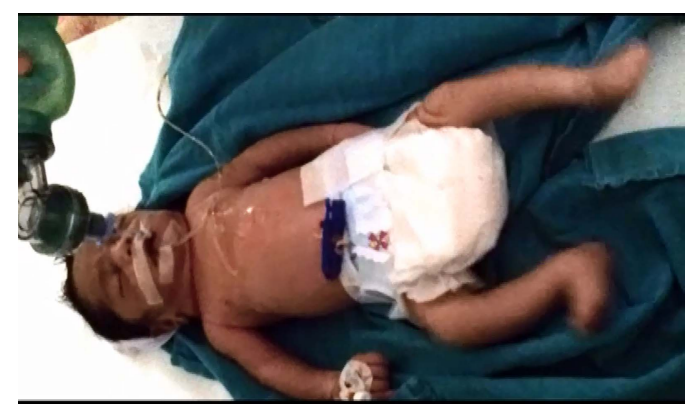

Video 2 Video is showing cycling movements of both lower limbs (a subtle type of seizure). 
and physical examination can, in the majority of cases, lead to finding the cause of the seizure. Laboratory investigations including blood sugar, calcium, serum electrolytes, lumbar puncture and metabolic work up are required if inborn error of metabolism is suspected. Other diagnostic modalities include EEG and MRI. ${ }^{7}$ The anticonvulsant of choice is phenobarbitone while the underlying cause is being determined and treated. ${ }^{8} 9$ More detailed descriptions can be read from the many expert reviews available. ${ }^{3}$

\section{Learning points}

- Neonatal seizures are of various types and have different manifestations; health care personnel should learn to distinguish between them.

- The aetiology of neonatal seizures must be searched out and the seizures treated appropriately.

- Neonatal seizures should be regarded as a medical emergency and all healthcare personnel should be instructed in their treatment.
Contributors AP and DS wrote the primary manuscript. TP critically analysed the manuscript and made corrections before submission. SM made final corrections before submission.

Competing interests None.

\section{Patient consent Obtained.}

Provenance and peer review Not commissioned; externally peer reviewed.

\section{REFERENCES}

1 Boylan GB, Pressler RM. Neonatal seizures: the journey so far. Semin Fetal Neonatal Med 2013;18:173-4.

2 Vasudevan C, Levene M. Epidemiology and aetiology of neonatal seizures. Semin Fetal Neonatal Med 2013;18:185-91.

3 Silverstein FS, Jensen FE. Neonatal seizures. Ann Neurol 2007;62:112-20.

4 Uria-Avellanal C, Marlow N, Rennie JM. Outcome following neonatal seizures. Semin Fetal Neonatal Med 2013;18:224-32.

5 Holmes GL, Ben-Ari Y. The neurobiology and consequences of epilepsy in the developing brain. Pediatr Res 2001;49:320-5.

6 Cross JH. Differential diagnosis of epileptic seizures in infancy including the neonatal period. Semin Fetal Neonatal Med 2013;18:192-5.

7 Hallberg B, Blennow M. Investigations for neonatal seizures. Semin Fetal Neonatal Med 2013;18:196-201.

8 van Rooij LG, Hellström-Westas L, de Vries LS. Treatment of neonatal seizures. Semin Fetal Neonatal Med 2013;18:209-15.

9 Pressler RM, Mangum B. Newly emerging therapies for neonatal seizures. Semin Fetal Neonatal Med 2013;18:216-23.

Copyright 2014 BMJ Publishing Group. All rights reserved. For permission to reuse any of this content visit http://group.bmj.com/group/rights-licensing/permissions.

BMJ Case Report Fellows may re-use this article for personal use and teaching without any further permission.

Become a Fellow of BMJ Case Reports today and you can:

- Submit as many cases as you like

- Enjoy fast sympathetic peer review and rapid publication of accepted articles

- Access all the published articles

- Re-use any of the published material for personal use and teaching without further permission

For information on Institutional Fellowships contact consortiasales@bmjgroup.com

Visit casereports.bmj.com for more articles like this and to become a Fellow 